\title{
PHYSIOLOGICAL, BIOCHEMICAL AND MOLECULAR CHARACTERIZATION OF POTENTIAL BACTERIOCIN PRODUCING STRAIN ISOLATED FROM FERMENTED BERSEEM
}

\author{
V. Bali, P.S. Panesar* and M.B. Bera \\ Food Biotechnology Research Laboratory, Department of Food Engineering and Technology, \\ Sant Longowal Institute of Engineering and Technology, Longowal - 148106. India
}

(Received: 7 August 2012; accepted: 13 November 2012)

\begin{abstract}
Lactic acid bacteria in fermented foods help in the improvement of flavour, preservation of the nutritive values of the raw material, and inhibition of growth or killing of food spoilage and pathogenic bacteria. Beside other metabolites, the produced bacteriocin, which is a ribosomally synthesized antimicrobial peptide, is the major metabolite involved in the killing of food spoilage microorganisms and acts as a biopreservative. In search of a bacteriocin having specific inhibitory activity against food pathogenic bacteria, isolation of bacteriocin producing lactic acid bacteria from various food items was carried out. Based on maximum production of the bacteriocin, strain BS13 was characterized and was further identified as Enterococcus faecium BS13 on the basis of physicochemical properties and $16 \mathrm{~S}$ rRNA analysis. In MRS medium this isolate presented the maximum production of bacteriocin (27 $306 \mathrm{AU} \mathrm{ml}^{-1}$ ) after $18 \mathrm{~h}$ of incubation period. BS13 bacteriocin showed antimicrobial activity against a wide range of bacteria, including Bacillus subtilis, Staphylococcus sp., Pediococcus sp., Listeria monocytogenes and Lactobacillus sp.
\end{abstract}

Keywords: bacteriocin, Enterococcus, isolation, lactic acid bacteria, characterization

Exploitation of lactic acid bacteria (LAB) from fermented food for the production of bacteriocin has importance both in basic and applied research. Excessive use of antimicrobial drugs in humans, animals, agriculture and food items resulted in the development of resistance among pathogenic microbes (SiLVA et al., 2010). LAB bacteriocins, in addition to closely related species, inhibit food pathogenic and food spoilage microorganisms (Ross et al., 2002), adding up to their potential of being considered as natural and non-toxic preservatives. As lactic acid bacteria are involved in various fermented foods since long and Generally Recognised as Safe (GRAS), extensive work is being carried out to find bacteriocins from these bacteria with wide range of temperature and $\mathrm{pH}$ stability (Moon et al., 2004).

The genus Enterococcus includes more than thirty different species of Gram-positive and heterofermentative bacteria that belong to the group of microorganisms known as lactic acid bacteria (SPARo et al., 2006). Enterococci are being used as effective probiotics and starter culture for various fermented food, meat and dairy products. Due to their ability to metabolize citrate and having proteolytic and lipolytic activity, they contribute to the organoleptic properties in ripening of Mozzarella, Cheddar, Taleggio cheese (Tzanetakis \& LitopoulouTZANETAKI, 1992; GirAfFA et al., 1995) and black olives (FrAnz et al., 1996). They are considered as infectious agents mainly in case of immuno-compromised hosts. Enterocin is produced by various strains of Enterococcus spp. against Listeria monocytogenes (VILLANI et al., 1993), a causative agent for food borne listeriosis. Thus, due to these characteristics there

\footnotetext{
* To whom correspondence should be addressed.

Phone: +91-1672-253252; fax: +91-1672-280057; e-mail: pspanesarrr@yahoo.com
} 
is increased interest in enterococci in the last few decades. They are widely distributed in nature like soil, plants, vegetables, municipal sewage, surface water, etc. (MAREKOVA et al., 2007). They have the ability to produce antimicrobial peptides, which act against pathogenic microorganisms present in the food. These small secreted peptides are termed as enterocins (FrAnZ et al., 2003). Use of bacteriocin producing strains or bacteriocin from Enterococcus is widely reported. A number of enterocins produced by enterococci have been characterised, including bacteriocin AS 48 (MAQUEDA et al., 2004), enterocin Q (CINTAS et al., 2000) and enterococcin EFS2 (MAISNIER-PATIN et al., 1996). To explore the possibility of isolation of a novel bacteriocin, screening of various fermented food items has been carried out. Thus, the present paper is focused on the phenotypic and genotypic characterization of the selected best bacteriocin producing LAB isolate with a wide spectrum of antibacterial activity.

\section{Materials and methods}

\subsection{Isolation of strain for bacteriocin production}

A number of 125 lactic acid bacteria were isolated from different samples of fermented foods and berseem (Trifolium alexandrinum) collected from the local market. All lactic acid bacteria isolates were cultivated in MRS broth (Himedia) at $30^{\circ} \mathrm{C}$. The indicator strains and reference strains, including Bacillus subtilis MTCC 441, Escherichia coli MTCC 118, Staphylococcus aureus NCDC 110, Enterococcus faecium DSMZ 20477, Pediococcus acidilactici LB 42, Lactobacillus sakei DSM 100017 and Listeria monocytogenes MTCC 657 were obtained from Microbial Type Culture Collection (MTCC), Institute of Microbial Technology, Chandigarh (India) and National Dairy Research Institute (NDRI), Karnal, Haryana, India.

Strains were screened for the production of bacteriocin using agar spot and welldiffusion assay techniques (Schillinger \& LuCKe, 1989). Stock cultures were maintained in glycerol stocks at $-20^{\circ} \mathrm{C}$. Among the isolates tested, strain BS13 was selected based upon the highest production of bacteriocin and its widest antimicrobial spectrum against different pathogenic strains, and was investigated in the present study.

\subsection{Growth and antimicrobial pattern of strain BS13}

Strain BS13 was grown on MRS medium at $37{ }^{\circ} \mathrm{C}$ at 100 r.p.m. for 48 h. Samples were collected after every $6 \mathrm{~h}$. Growth was measured in terms of optical density (OD) at $600 \mathrm{~nm}$. The broth was centrifuged at 10000 r.p.m. for $10 \mathrm{~min}$ at $4{ }^{\circ} \mathrm{C}$. Supernatant was filtered through pre-sterilized $0.22 \mu \mathrm{m}$ filters (HiMedia, Mumbai). The supernatant obtained was used as crude bacteriocin. To eliminate the possibility of inhibition by hydrogen peroxide and lactic acid, dilutions were prepared from the neutralized supernatant and well-diffusion assay was performed. Bacteriocin activity was calculated as reciprocal of dilutions indicating inhibition of indicator lawn and expressed in activity units per $\mathrm{ml}\left(\mathrm{AU} \mathrm{ml} \mathrm{m}^{-1}\right)$.

Antimicrobial activity assay against various pathogenic and indicator strains was performed. Plates were incubated at $30^{\circ} \mathrm{C}$ for overnight and zone of inhibition were examined. To confirm the proteinaceous nature of the bacteriocin, enzymes (trypsin and proteinease $\mathrm{K}$ ) were added at the concentration of $1 \mathrm{mg} \mathrm{ml}^{-1}$ to the bacteriocin suspension. The mixture was incubated at $37^{\circ} \mathrm{C}$ for $30 \mathrm{~min}$ then tested with assay reaction (BADARINATH \& HALAMI, 2011). 


\subsection{Morphological and physiological characteristics}

Morphological analysis of the selected strain BS13 and culture characteristics were performed for parameters like Gram staining, shape, size, presence of spore and motility of the isolate by standard methods. The isolate was inoculated in nutrient broth at different $\mathrm{pHs}$ ranging from 3 to 12, at different incubating temperatures ranging between 10 to $90{ }^{\circ} \mathrm{C}$ and in different amounts of sodium chloride $(\mathrm{NaCl})$ ranging from 1 to $10 \%$ followed by observation of growth.

\subsection{Electron microscopy of selected strain}

The cells were suspended in phosphate buffer, fixed with $2.5 \%$ glutaraldehyde prepared in phosphate buffer for 30-40 min. The cells were dehydrated with ethyl alcohol before making a uniform layer on silver adhesive tape glued to the scanning electron microscope stubs. The stubs were conducted by sputtering gold. The conducted stubs were examined under JEOL 6100 SEM.

\subsection{Biochemical characteristics}

The isolate was inoculated onto slants and in tubes containing various carbohydrates, and fermentation pattern was obtained by the detection of gas production. The selected strain was studied for anaerobic growth, nitrite and nitrate reduction, production of catalase, production of indole, Voges-Proskauer (VP) test, Methyl Red (MR) test, hydrolysis of starch, arginine, gelatin, casein, aesculin, urea, degradation of lysozyme and oxidase test.

\subsection{Antibiotic sensitivity test}

The sensitivity of the isolate towards various antibiotics was determined by spreading the overnight culture of the isolate on nutrient agar plate. The antibiotic discs ( $7 \mathrm{~mm}$ in diameter) were placed onto it at appropriate distances. The growth of the isolate was observed after overnight incubation at $37^{\circ} \mathrm{C}$ and diameters of the zones of growth inhibition were measured. The commercially available antibiotic discs (Hi Media, Mumbai, India), including ampicillin $\left(\mathrm{AMP}^{2}\right)$, tetracycline $\left(\mathrm{TE}^{10}\right)$, nitrofurantoin $\left(\mathrm{NIT}^{100}\right)$, polymyxin-B $\left(\mathrm{PB}^{50}\right)$, bacitracin $\left(\mathrm{B}^{10}\right)$, neomycin $\left(\mathrm{N}^{30}\right)$, streptomycin $\left(\mathrm{S}^{25}\right)$, novobiocin $\left(\mathrm{NV}^{30}\right)$, erythromycin $\left(\mathrm{E}^{10}\right)$, penicillin- $\mathrm{G}\left(\mathrm{P}^{2}\right)$, methicillin $\left(\mathrm{MET}^{30}\right)$, kanamycin $\left(\mathrm{K}^{5}\right)$ and chloroamphenicol $\left(\mathrm{C}^{30}\right)$, were used.

\subsection{DNA isolation and PCR amplification of $16 S \mathrm{rRNA}$}

Genomic DNA of the isolated strain was isolated by SAMBrooK and Russel (2001) with little modification. 27F (5'-AGAGTTTGATCCTGGCTCAG-3') and 1492R (5'-TACGGYTACCTTGTTACGACTT-3'), 341F (5'CTGGGAGGCAGCAGTGGG3'), 786F (5'GATTAGATACCCTGGTAG3'), 536R (5'GTATTACCGCGGCTGCTG3') were used for the amplification of 16S rRNA gene using MyCycler Thermal cycler (BioRad, USA). In PCR solution, i.e. template DNA $2.5 \mu$ ( (1:4 dilution), $1 \mu 1$ Taq polymerase, $0.5 \mu 1$ dNTPs mixture, amplification was carried out for 35 cycles following the conditions $1 \mathrm{~min}$ at $94{ }^{\circ} \mathrm{C}, 50 \mathrm{~s}$ at $50{ }^{\circ} \mathrm{C}, 1 \mathrm{~min} 45 \mathrm{~s}$ at $72{ }^{\circ} \mathrm{C}$ followed by extension for $5 \mathrm{~min}$ at $72{ }^{\circ} \mathrm{C} .16 \mathrm{~S}$ sequencing was done from Bioserve Biotechnologies (India) Pvt. Ltd., A.P., India. DNA sequencing sample was processed using ABI 3130 (4 capillary) and 3730Xl (96 capillary) electrophoresis instruments with internal sequence control (pGEM) to ensure the quality of the complete DNA sequence process. 


\subsection{S rRNA gene sequencing analysis}

DNA sequence data analysis was performed using BLAST from the National Centre for Biotechnology Information database (http://www.ncbi.nlm.nih.gov/recipon/blast-search. html). Multiple sequence similarity was analysed using CLUSTAL W program version 1.6 (Genetics Computer Group package). The phylogenetic tree was prepared using the neighbour-joining algorithm (SAITOU \& NEI, 1987) of the program MEGA (Molecular Evolutionary Genetics Analysis). The similarity matrix was calculated by the method of Jukes and Cantor (FrANZ et al., 1996) in the MEGA programme.

The GenBank accession number of the sequence reported in this paper is JQ429446.

\section{Results and discussion}

Forty lactic acid bacteria producing bacteriocin were isolated from various fermented food items and tested against different indicator strains for their antimicrobial activity. Strain BS13 was selected based on the produced quantity of bacteriocin and its antimicrobial spectrum (BALI et al., 2011). Bacteriocin production was confirmed by application of $\mathrm{pH}$ neutralized supernatant for the determination of inhibition of indicator strains. On addition of different proteolytic enzymes, the bacteriocin lost the antimicrobial effect on the indicator strains, thereby, confirming the protein nature of the product (LEE et al., 2002). Morphological and physiological characterization of the strain was examined according to the Bergey's Manual of Determinative Bacteriology (SNEATH, 1986) as shown in Table 1. The strain is Gram positive, catalase negative cocci, and mostly arranged in pairs or chains. The strain was able to grow at a temperature range of $15-60{ }^{\circ} \mathrm{C}$ and $\mathrm{pH}$ in the range of 4 to 9.5 . These characteristics are similar to enterococci (Moon et al., 2004). The electron microscopy of stain BS13 showed coccus-shaped bacterium usually spherical, although some appear oval, elongated or flattened on one side, and typically occurring in pairs of two joined cells (diplococcus). Most cocci are approximately $0.5-1.0 \mu \mathrm{m}$ in diameter and may be seen, based on their planes of division and tendency to remain attached after replication, in one of the arrangements presented in Fig. 1. Different pathogenic and indicator strains were tested for their susceptibility towards BS13 bacteriocin (Table 2). Maximum inhibition was observed against Enterococcus faecium DSMZ 20477 and Staphylococcus aureus NCDC 110. Variable levels of inhibition with different Gram-positive strains (13-28 mm of zone) were observed. However, this bacteriocin also inhibited Gram-positive Escherichia coli MTCC 118, a characteristic different from Enterococcus sp. K25 (Moon et al., 2004). Biochemical characterization and carbohydrate utilization of the strain were done as shown in Tables 3 and 4, respectively. Similarly, Enterococcus EFS2 showed inhibition of Gram-positive strains, like L. monocytogenes, and not of Gram-negative bacteria (MAISNIER-PATIN et al., 1996). Enterococcus faecium BS13 showed resistance to polymycin B and kanamycin, however, great sensitivity to penicillin $\mathrm{G}$, erythromycin and tetracycline was observed (Table 5). 
Table 1. Morphological and physiological characterization of Enterococcus faecium BS13

\begin{tabular}{ll}
\hline Characteristics & Result \\
\hline Colony morphology & $\begin{array}{l}\text { White small, round with smooth margins, elevated } \\
\text { colonies, facultative anaerobic, non-motile, } \\
\text { non-spore forming }\end{array}$ \\
Growth in liquid medium & $\begin{array}{l}\text { Sedimentary growth with characteristic smell } \\
\text { Gram stain }\end{array}$ \\
Cell shape & Cocci \\
Cell arrangement & Mostly chains/double rarely single \\
Growth at different temperature & $\pm 15-60{ }^{\circ} \mathrm{C}$ \\
Growth at different pH & $4.0-9.5$ \\
Growth at different NaCl concentration & $1.0-8.0^{\circ} \%$ \\
Growth on different media & \\
Nutrient agar & Positive \\
Sabouraud Dextrose agar & Negative \\
Chitin agar & Negative \\
Mac Conkey agar & Negative \\
MRS agar & Positive \\
\hline
\end{tabular}

Table 2. Comparison of inhibitory spectrum of Enterococcus faecium BS13 isolate against different microorganisms using agar spot assay

\begin{tabular}{lc}
\hline Target strain & Zone of inhibition (mm) \\
\hline Bacillus subtilis MTCC 441 & 16 \\
Escherichia coli MTCC 118 & 24 \\
Escherichia coli ATCC 25922 & 18 \\
Staphylococcus aureus NCDC 110 & 24 \\
Staphylococcus aureus MTCC 737 & 24 \\
Enterococcus faecium DSMZ 20477 & 25 \\
Enterococcus faecalis ATCC 29212 & No zone \\
Pediococcus acidilactici LB 42 & 18 \\
Pediococcus pentosaceus MTCC 3817 & 18 \\
Lactobacillus sakei DSM 100017 & 13 \\
Lactococcus lactis MTCC 440 & 15 \\
Lactobacillus brevis MTCC 1750 & 18 \\
Listeria monocytogenes MTCC 657 & 15 \\
Listeria monocytogenes ATCC 53135 & 18 \\
Lactobacillus rhamnosus NCDC 018 & 16 \\
Lactobacillus delbrueckii NCDC 03 & 25 \\
Bacillus cereus MTCC 1272 & 15 \\
\hline
\end{tabular}


Table 3. Biochemical characterization of Enterococcus faecium BS13

\begin{tabular}{llll}
\hline Test & Result & Test & Result \\
\hline Catalase test & Negative & Starch hydrolysis & Negative \\
Dihydroxyacetone & Positive & Casein hydrolysis & Negative \\
Methyl Red test & Positive & Aesculin hydrolysis & Positive \\
Voges-Proskauer test & Negative & Lysine decarboxylase presence & Negative \\
Sodium azide test & Positive & Urea hydrolysis & Negative \\
Presence of nitrite & Positive & Arginine hydrolysis & Positive \\
After adding zinc dust & Negative & Gelatin hydrolysis & Negative \\
Degradation of lysozyme & Negative & ONPG hydrolysis & Positive \\
\hline
\end{tabular}

Table 4. Carbohydrate utilization (acid production) by Enterococcus faecium BS13

\begin{tabular}{|c|c|c|c|c|c|}
\hline Carbohydrate & Results & Carbohydrate & Results & Carbohydrate & Results \\
\hline Lactose & + & Raffinose & - & Adonitol & - \\
\hline D-xylose & - & Trehalose & + & D-arabinose & - \\
\hline Maltose & + & Melibiose & - & L-arabinose & - \\
\hline Fructose & + & Sucrose & + & Erythritol & - \\
\hline Dextrose & + & L-arabinose & + & D-lyxose & - \\
\hline D-galactose & + & D-mannose & + & 2-ketogluconate & - \\
\hline Inulin & + & Salicin & + & Inositol & - \\
\hline Sodium glyconate & - & Glucosamine & + & Glycogen & - \\
\hline Glycerol & + & Dulcitol & - & Inulin & - \\
\hline Inositol & - & Adonitol & - & Melezitose & - \\
\hline Methyl- $\alpha$-D-mannoside & + & Methyl- $\alpha$-D-glucoside & + & Methyl- $\beta$-xyloside & - \\
\hline D-mannitol & + & D-ribose & + & D-glucose & + \\
\hline Rhamnose & - & Meleitose & + & D-arabitol & - \\
\hline Cellobiose & + & Sorbitol & - & L-arabitol & - \\
\hline Xylitol & - & Esculin & + & D-fucose & - \\
\hline Citrate & - & D-arabinose & + & L-fucose & - \\
\hline L-sorbose & - & Malonate & - & Rhamnose & - \\
\hline D-amygdalin & + & Glucose & + & D-tagatose & - \\
\hline$\beta$-Gentiobiose & + & Arbutin & + & Raffinose & - \\
\hline$N$-acetylglucosamine & + & Dulcitol & + & Trehalose & - \\
\hline Salicin & - & Gluconate & + & L-xylose & - \\
\hline
\end{tabular}


Table 5. Antibiotic sensitivity test for Enterococcus faecium BS13

\begin{tabular}{lll}
\hline Antibiotic & Amount & Zone diameter (mm) \\
\hline Ampicillin $\left(\mathrm{AMP}^{2}\right)$ & $2 \mathrm{mcg} / \mathrm{disc}$ & 17 (Sensitive) \\
Tetracycline $\left(\mathrm{TE}^{10}\right)$ & $10 \mathrm{mcg} / \mathrm{disc}$ & 19 (Sensitive) \\
Nitrofurantoin $\left(\mathrm{NIT}^{100}\right)$ & $100 \mathrm{mcg} / \mathrm{disc}$ & 15 (Sensitive) \\
Polymyxin-B $\left(\mathrm{PB}^{50}\right)$ & $50 \mathrm{units} / \mathrm{disc}$ & No zone (Resistant) \\
Bacitracin $\left(\mathrm{B}^{10}\right)$ & $10 \mathrm{units} / \mathrm{disc}$ & 12 (Sensitive) \\
Neomycin $\left(\mathrm{N}^{30}\right)$ & $30 \mathrm{mcg} / \mathrm{disc}$ & 18 (Sensitive) \\
Streptomycin $\left(\mathrm{S}^{25}\right)$ & $25 \mathrm{mcg} / \mathrm{disc}$ & 8 (Sensitive) \\
Novobiocin $\left(\mathrm{NV}^{30}\right)$ & $30 \mathrm{mcg} / \mathrm{disc}$ & 11 (Sensitive) \\
Erythromycin $\left(\mathrm{E}^{10}\right)$ & $10 \mathrm{mcg} / \mathrm{disc}$ & 20 (Sensitive) \\
Penicillin- $\left(\mathrm{P}^{2}\right)$ & $2 \mathrm{units} / \mathrm{disc}$ & 23 (Sensitive) \\
Methicillin $\left(\mathrm{MET}^{30}\right)$ & $30 \mathrm{mcg} / \mathrm{disc}$ & 13 (Sensitive) \\
Kanamycin $\left(\mathrm{K}^{5}\right)$ & $5 \mathrm{mcg} / \mathrm{disc}$ & No zone (Resistant) \\
Chloroamphenicol $\left(\mathrm{C}^{30}\right)$ & $30 \mathrm{mcg} / \mathrm{disc}$ & 27 (Sensitive) \\
\hline
\end{tabular}

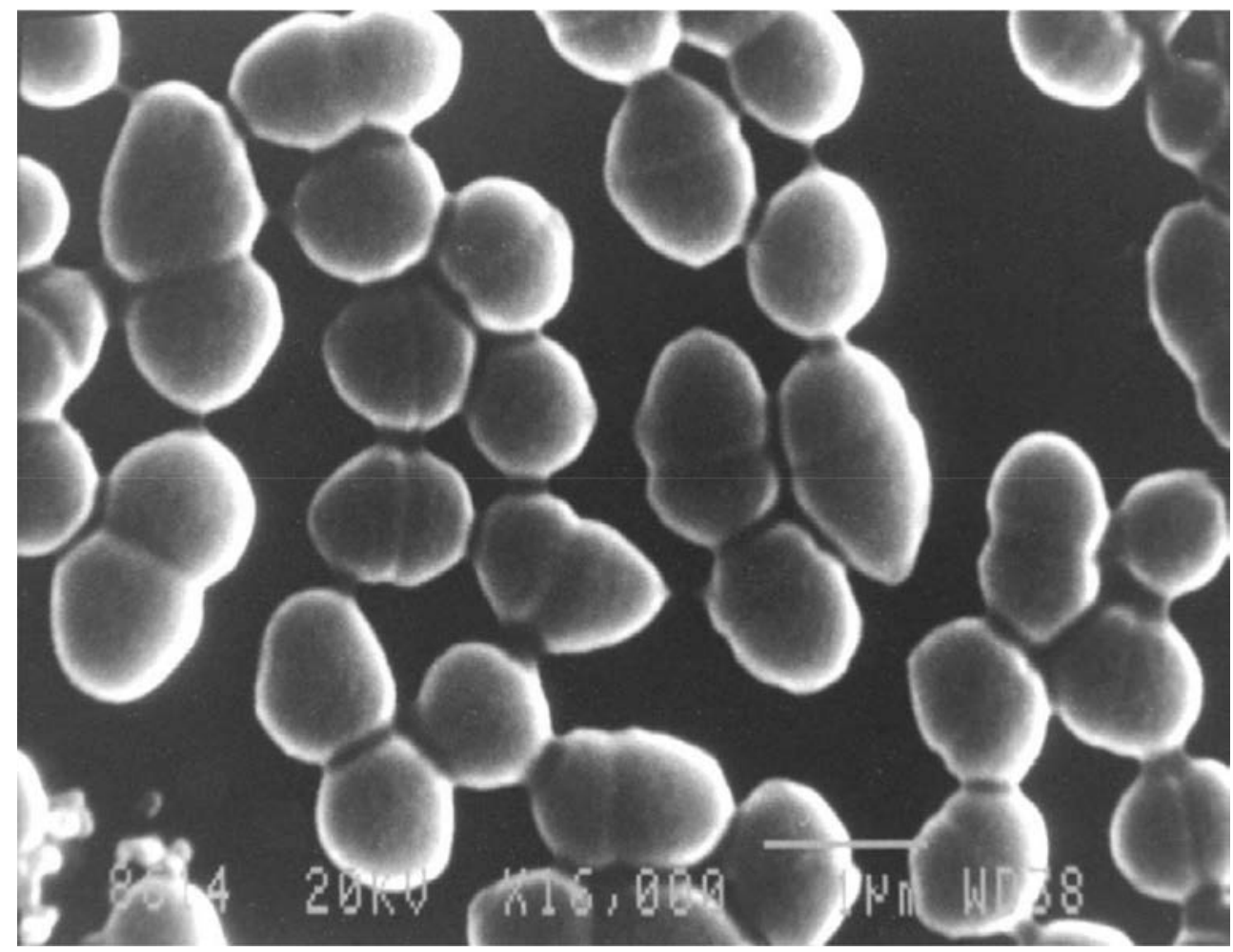

Fig. 1. Scanning electron micrograph of newly isolated bacterial strain Enterococcus faecium BS13 


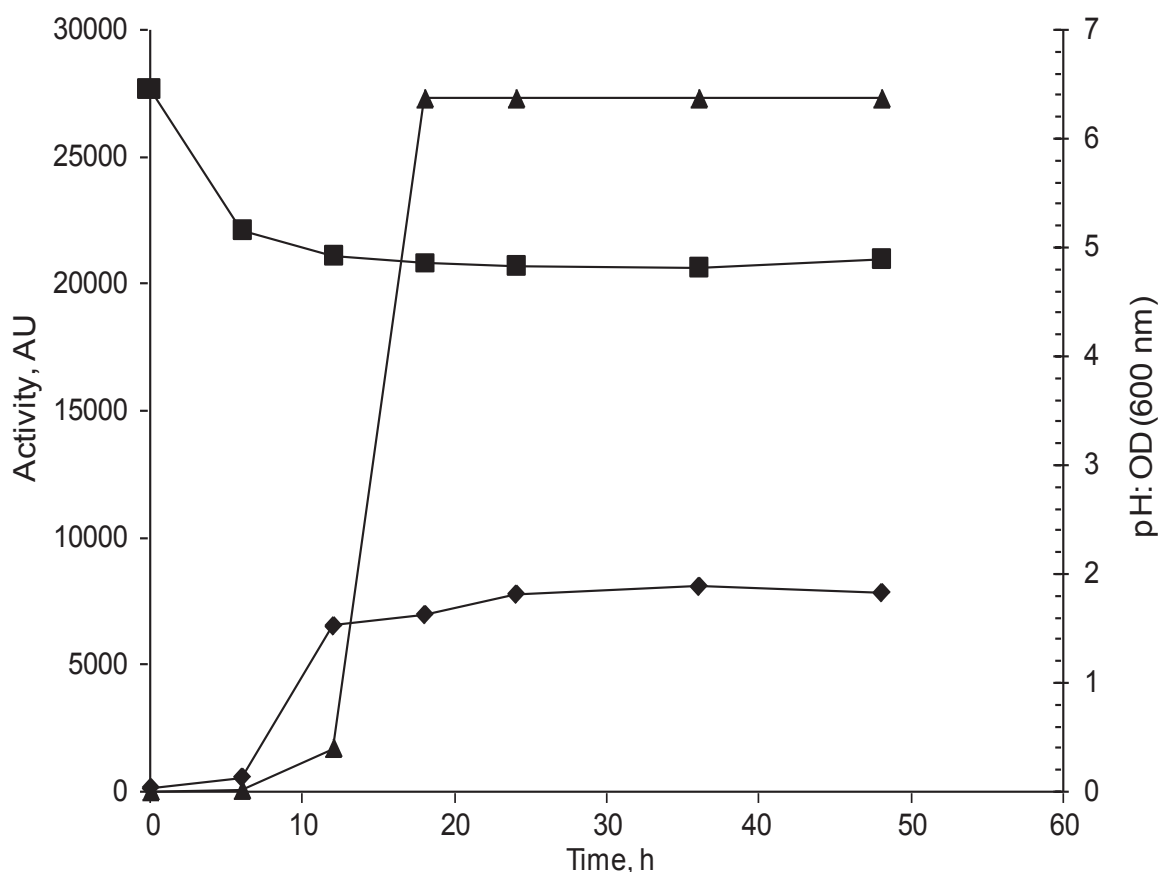

Fig. 2. Growth and bacteriocin production of Enterococcus faecium BS13 in MRS medium $\boldsymbol{\Lambda}$ : Activity (AU); $\diamond:$ OD (600 nm); $\mathbf{\square}: \mathrm{pH}$

Strain BS13 was grown in MRS medium at $30{ }^{\circ} \mathrm{C}$ for $48 \mathrm{~h}$. Maximum growth (OD 1.897) was observed after $36 \mathrm{~h}$ of incubation. Production of bacteriocin starts under $6 \mathrm{~h}$ of incubation and maximum activity (27306 $\mathrm{AU} \mathrm{ml}^{-1}$ ) was recorded after 18-24 h of growth corresponding to the start of the stationary phase and was stable up to $36 \mathrm{~h}$ (Fig. 2). The $\mathrm{pH}$ of the medium started decreasing from $6 \mathrm{~h}$ onwards and a $\mathrm{pH}$ of 4.97 was observed after 36 $\mathrm{h}$ of incubation. All these properties matched well with characteristics of the enterococci (Moon et al., 2004). In order to confirm the identification of the strain, 16S rRNA sequencing was performed (Fig. 3). Homology of the sequence was analysed by BLAST program at NCBI. Two strategies were applied to construct phylogenetic tree, i.e. Character based and Distance based. Under the Character based method, maximum likelihood algorithm was used, which is based directly on the sequence characters rather than on pair-wise distances. Similarly under the Distance based method, Neighbor-Joining (NJ) algorithm was used to build NJ trees, which were based upon the pair-wise distance/dissimilarities. Character based methods count mutational events present on the sequences and may therefore avoid the loss of information when characters are converted to distances, whereas Distance based method measures the pair-wise distance/dissimilarity between two sequences and constructs the tree totally from the resultant distance matrix. Considering the advantages and disadvantages, both types of strategies were applied. The tree constructed using the Character based method shows that our query sequence is very closely related to the sequence from Enterococcus faecium strain LMG 11423 (NR_042054.1, gi 343201328). The tree also indicates that our query sequence is distantly related to Pilibacter termitis (NR_042949.1, gi 343202583). Other entries closely related to the query sequence in the same taxa include Enterococcus 
thailandicus, Enterococcus durans and Enterococcus mundtii. It is clear from the the that the query sequence belongs to the Enterococcus clan and also shows distant relationship with the taxa of Melissococcus, Catellicoccus, Tetragenococcus, Vegococcus and Pilibacter. Similar types of inferences were also found in the tree build using Distance based method, i.e. NJ, which further confirms that the query sequence belongs to the Enterococcus family. Molecular phylogenetic analysis was carried out by Maximum Likelihood method (TAMURA \& NEI, 1993). This analysis involves 49 nucleotide sequences. All gaps and missing data were eliminated. There were a total of 1145 positions in the final dataset. Evolutionary analysis was conducted in MEGA5 (TAMURA et al., 2011) and phylogenetic tree was constructing indication evolutionary relationship (Fig. 4). Optimization of process parameters for the production and characterization of bacteriocin BS13 is being carried out.

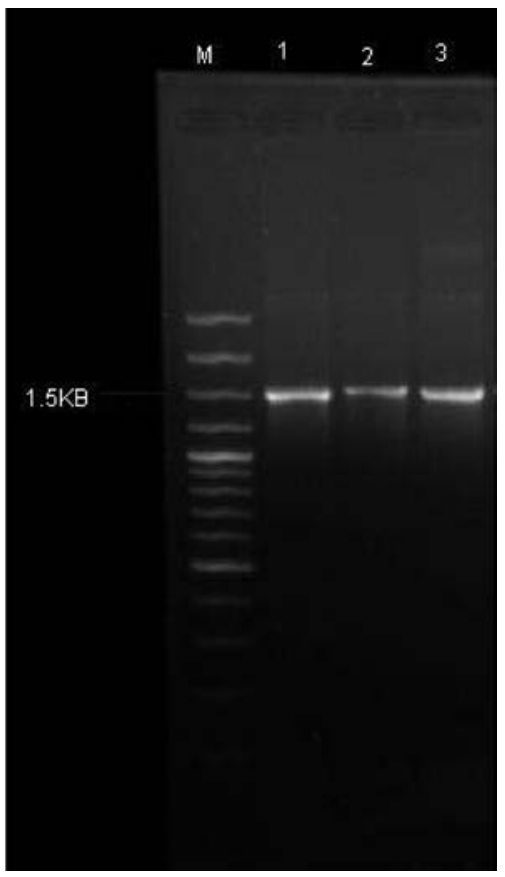

Fig. 3. PCR amplified 16S RNA from Enterococcus faecium BS13

Lane M: standard marker; Lanes 1-3 represent the 16S RNA amplified products

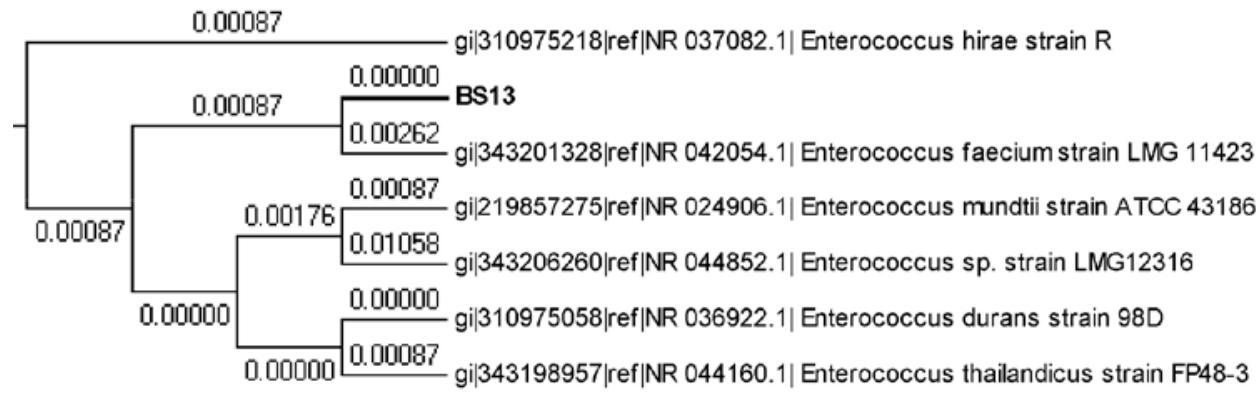

Fig. 4. Molecular phylogenetic analysis by Maximum Likelihood method 


\section{Conclusions}

Isolate BS13 inhibited wide range of bacteria, including Bacillus subtilis, Staphylococcus sp., Pediococcus sp., Listeria monocytogenes and Lactobacillus sp., and showed the best production of the bacteriocin. The strain was characterized and identified on the basis of physicochemical properties and 16S rRNA analysis. In MRS medium, the maximum production of bacteriocin (27306 $\mathrm{AU} \mathrm{m}^{-1}$ ) at $18 \mathrm{~h}$ and $\mathrm{pH} 4.9$ was observed by Enterococcus faecium BS13.

V. BALI is thankful to the Department of Science and Technology, New Delhi, India for providing INSPIRE fellowship.

\section{References}

Badarinath, V. \& Halami, P.M. (2011): Molecular characterization of class IIa, heat-stable enterocin produced by Enterococcus faecium MTCC 5153. Indian J. Biotechnol., 10, 307-315.

BALI, V., PANESAR, P.S. \& BERA, M.B. (2011): Isolation, screening and evaluation of antimicrobial activity of potential bacteriocin producing lactic acid bacteria isolate. Microbiol. J., 1, 113-119.

Cintas, L.M., Casaus, P., Herranz, C., Håvarstein, L.S., Holo, H., Hernández, P.E. \& Nes, I.F. (2000): Biochemical and genetic evidence that Enterococcus faecium L50 produces Enterocins L50A and L50B, the sec-dependent Enterocin P, and a novel bacteriocin secreted without an N-terminal extension termed Enterocin Q. $J$. Bacteriol., 182, 6806-6814.

Franz, C.M.A.P., Schillinger, U. \& Holzapfel, W.H. (1996): Production and characterisation of enterocin 900, a bacteriocin produced by Enterococcus faecium BFE 900 from black olives. Int. J. Fd Microbiol., 29, $255-270$.

Franz, C.M.A.P., Stiles, M.E., Schleifer, K.H. \& Holzapfel, W.H. (2003): Enterococci in foods - a conundrum for food safety. Int. J. Fd Microbiol., 88, 105-122.

Giraffa, G., Picchioni, N., Neviani, E. \& Carminati, D. (1995): Production and stability of an Enterococcus faecium bacteriocin during Taleggio cheesemaking and ripening. Fd Microbiol., 12, 301-307.

Lee, K., Moon, G., An, J., Lee, H., Chang H.C., Chung, D.K., Lee, J. \& Kim, J.H. (2002): Isolation of a Nisin producing Lactococcus lactis strain from Kimchi and characterization of its nisZ gene. J. Microbiol. Biotechnol., 12, 389-397.

Maisnier-Patin, S., Forni, E. \& Richard, J. (1996): Purification, partial characterisation and mode of action of enterococcin EFS2, an antilisterial bacteriocin produced by a strain of Enterococcus faecalis isolated from a cheese. Int. J. Fd Microbiol., 30, 255-270.

Maqueda, M., Gálvez, A., Sánchez-Barrena, M.J., González, C., Albert, A., Rico, M. \& Valdivia, E. (2004): Peptide AS-48: prototype of a new class of cyclic bacteriocins. Curr. Protein Peptide Sci., 5, 399-416.

Marekova, M., Laukova, A., Skaugen, M. \& Nes, I. (2007): Isolation and characterization of a new bacteriocin, termed enterocin M, produced by environmental isolate Enterococcus faecium AL41. J. Ind. Microbiol. Biotechnol., 34, 533-537.

Moon, G., Kang, C., Pyun, Y. \& Kim, W.J. (2004): Isolation, identification and characterization of a bacteriocin producing Enterococcus sp. from Kimchi and its application in Kimchi fermentation. J. Microbiol. Biotechnol., 14, 924-931.

Ross, R.P., Morgan, S. \& Hill, C. (2002): Preservation and fermentation: past, present and future. Int. J. Fd Microbiol., 79, 3-16.

Saitou, N. \& NeI, M. (1987): The Neighbor-Joining Method: a new method for reconstructing phylogenetic trees. Mol. Biol. Evol., 4, 406-425.

Sambrook, J. \& Russel, D.W. (2001): Molecular cloning: A laboratory manual, 3rd ed., Cold Spring Harbor Press, New York (USA). 2344 pages

SCHILlinger, U. \& LuCKe, F.K. (1989): Antibacterial activity of Lactobacillus sake isolated from meat. Appl. Environ. Microbiol., 55, 1901-1906.

Silva, N.C.B., Esquibe, M.A., Santos, J.E.S., Almeida, M.Z., Sampaio, C.S. \& Barros, T.F. (2010): In vitro antimicrobial activity of extracts from Abarema cochliacarpos (Gomes) Barneby and J.W. Grimes. Afr. J. Microbiol. Res., 4, 1654-1658. 
Sneath, P.H.A. (1986): Endospore-forming Gram-positive rods and cocci. In: Sneath, P.H.A., Nicholas, M.S., Sharpe, M.E. \& Holt, J.G. (Eds): Bergey's Manual of systematic bacteriology. Williams and Wilkins, Baltimore, MD, USA., pp. 1104-1139.

Sparo, M.D., Castro, M.S., Andino, P.J., Lavigne, M.V., Ceraini, C., Gutiérrez, G.L., Fernández, M.M., De Marzi, M.C., Malchiodi, E.L. \& Manghi, M.A. (2006): Partial characterization of enterocin MR99 from corn silage isolate of Enterococcus faecalis. J. Appl. Microbiol., 10, 1-19.

Tamura, K. \& Nei, M. (1993): Estimation of the number of nucleotide substitutions in the control region of mitochondrial DNA in humans and chimpanzees. Mol. Biol. Evol., 10, 512-526.

Tamura, K., Peterson, D., Peterson, N., Stecher, G., Nei, M. \& Kumar, S. (2011): MEGA5: Molecular Evolutionary Genetics Analysis using Maximum Likelihood, Evolutionary Distance, and Maximum Parsimony Methods. Mol. Biol. Evol., 28, 2731-2739.

Tzanetakis, N. \& Litopoulou-Tzanetaki, E. (1992): Changes in numbers and kinds of lactic acid bacteria in Feta and Teleme, two cheeses from ewe's milk. J. Dairy Sci., 75, 1389-1393.

Villani, F., Salzano, G., Sorrentino, E., Pepe, O., Marino, P. \& Coppola, S. (1993): Enterocin 226NWC, a bacteriocin produced by Enterococcus faecalis 226, active against Listeria monocytogenes. J. Appl. Bacteriol., 74, 380-387. 